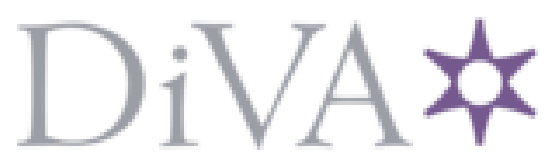

http://www.diva-portal.org

\title{
Postprint
}

This is the accepted version of a chapter published in Mediatization of Communication.

Citation for the original published chapter:

Bolin, G. (2014)

Institution, Technology, World: Relationships between the Media, Culture and Society.

In: Lundby, Knut (ed.), Mediatization of Communication (pp. 175-197). Berlin \& Boston: De

Gruyter Mouton

Handbooks of communication sciences

N.B. When citing this work, cite the original published chapter.

Permanent link to this version:

http://urn.kb.se/resolve?urn=urn:nbn:se:sh:diva-24980 


\title{
Göran Bolin
}

\section{Institution, technology, world: Relationships between the media, culture, and society}

[This is a pre-print of chapter 8 in Knut Lundby (ed.) (2014): Mediatization of

Communication, Berlin \& Boston: De Gruyter Mouton, pp. 175-197.]

\begin{abstract}
In this chapter three approaches to mediatization are discussed: the institutional, the technological, and the media as world. Each of these has a different ontological and epistemological background, and it is argued that this has consequences on which questions are posed, and which kinds of answers are possible to give. For these backgrounds it is accounted, with a special focus on how these approaches theorize the relationship between media and society, how media are defined and which historical perspective is privileged.
\end{abstract}

Keywords: mediatization, modernity, second modernity, media technologies, cultural technologies, culture, society, Baudrillard, structuralism

\section{Introduction: The different strands of mediatization}

The widespread popularity of the concept of mediatization has, as is usually the case with popular concepts, brought with it a range of different uses, interpretations, and perspectives. All these perspectives are based in specific epistemological approaches, in turn possible to relate to basic ontological standpoints. In this context I want to focus on three such areas where clarification is needed. Firstly, different takes on mediatization vary in their views of the relationship between the media and society: How can we understand this relationship? What is the possible impact of the media on society? Or what roles do we ascribe the media in mediatization processes? Secondly, and following from the first, it is not always entirely clear what is meant by "the media", and although various theorists do mention the mass media and digital media, we seldom see differentiation between different types of media in mediatization theory; thus, one could ask whether all media play the same role in social and cultural processes. And although many refer to the media as mass media or digital media, there are few who distinguish between media as organizations and as technologies. Thirdly, although most mediatization theories describe and analyse processes and thus implicitly deal with historical change or modernization processes, the specificities of their historical perspectives are seldom discussed at length.

Against the background of these three areas of enquiry, I want to discuss three mediatization approaches. Firstly, I will account for the "institutional" perspective, focusing on the media as institutions and how they have related to other social and cultural institutions. As this account is well represented in the literature, I will deal with it quite briefly. Secondly, I will describe the "technological" approach to mediatization, emphasizing the technological impact of the media on wider social and cultural processes. Thirdly, I will contrast these two perspectives with the "media as world" perspective. This perspective is less insistent on theorizing the concept of mediatization, to the benefit of a more general discussion on the role of media in culture and society. If the two first perspectives emphasize historical linearity and process in an objectivist manner, the "media as world" perspective is more phenomenological in the sense that it adds an experiential dimension, and is hence more subjectivist. While the two first perspectives, from an objectivist position, focus 
on the question "What does it look like?", the third adds the phenomenological question "What does it feel like?". The following discussion will emphasize the consequences of each of these perspectives on the analysis of the roles and relationships between media, communication, culture, and society.

To be clear from the outset, I do not argue that any of these are "wrong" and that there is one, superior and "right" version of mediatization theory. Although I should also make it clear from the outset that I, like anyone else, speak from a certain position and have preferences when it comes to these perspectives, it should be emphasized that they are rooted in the fact that each one opens up for different sets of questions, and that my preferences are based in these sets of questions and not on the intent to dismiss any of the approaches as false, wrong or reductionist.

\section{The institutional perspective}

Quite often in accounts of mediatization the media are theorized in their capacity as institutions, and as such are seen as an external force that has come to affect other social institutions and social life (e.g. Asp 1990; Strömbäck 2008). This take on mediatization builds on a specific set of ontological and axiomatic presuppositions about the nature of society, which often takes its departure in the "media logic" theory of Altheide and Snow (1979). This is the "processual" (Krotz 2007) or the “institutional" (Lundby 2009a: 5; Hepp [2011] 2013: 42; Hjarvard 2013: 4) perspective on mediatization, focusing on institutionalizing processes on the meso level, for example in journalism.

This perspective is founded on the drive for causal explanation, and with it follows a specific linear historical perspective whereby events follow in causal order, and the historical direction is described in terms of progress (or, indeed, decline). It is also based in the analysis of institutions, or spheres, related to one another, as exemplified in this quote from Jesper Strömbäck: "The process of the mediatization of politics can be described as a process through which the important question involving the independence of the media from politics and society concludes with the independence of politics and society from the media" (Strömbäck 2008: 241). The quote sets up "society" as separate from "politics" as well as "the media", all of which are seemingly independent from each other. In the article, Strömbäck also marks out "four phases" of the mediatization process, in the first of which - "the media" becomes "the most important source of information and channel of communication between the citizenry and political institutions" (Strömbäck 2008: 236). Following from this, there was a time when "political institutions" operated without the influence of "the media", while today these institutions have been invaded, or subsumed, by the media. This quote obviously only makes sense if by media we mean mass media institutions, for example the institution of journalism, as one could well argue that modern mass democracies have never been and could never function without some form of mediating technologies extending the human body (in antiquity, for example in ancient Greece, rhetoric was clearly a communications technology used for political purposes, although not one that extended the human body).

The ways of looking at the relationship between media, society, and other social institutions (politics, the economy, education, etc.) naturally differ between scholars. One can also, for example in Stig Hjarvard's extensive writing from within an institutional perspective, see a gradual nuancing or fine-tuning of these relationships, most explicitly in the introductory chapter of his recent The Mediatization of Society (Hjarvard 2013), where he emphasizes the "role of the media in culture and society" (p. 2, my emphasis). With this he points to "culture" and 
"society" as larger and more encompassing entities, within which social and cultural institutions are then related to one another.

Describing these relationships is a delicate matter, and there are also instances in Hjarvard's earlier writings that are more unclear when it comes to this relationship, for example in his oft-quoted definition of mediatization as "the process whereby society to an increasing degree is submitted to, or become dependent on, the media and their logic. This process is characterized by a duality in that the media have become integrated into the operations of other social institutions, while they also have acquired the status of social institutions in their own right" (Hjarvard 2008: 113). This quote seems to imply, if we think of "the media" as institutions (for example, journalistic news media), that they are separate from "society" and that their logics would then also be developed from society's outside. There is, however, another way to read this quote, thinking of the media here not as institutions but rather as technologies having become integrated into other social institutions (that then to a certain extent relate to these technologies in specific ways). Such a reading would perhaps make more sense.

The advantage of the institutional perspective is that it can easily be operationalized into the analysis of powerful media institutions affecting or influencing various social processes in society - or from society's outside, as some seemingly suggest. Thus there is a wealth of studies engaging in the mediatization of politics (e.g. Asp 1990; Strömbäck 2008; Mazzoleni and Schulz 1999), war (e.g. McQuail 2006), religion (e.g. Hjarvard and Lövheim 2012), fashion (Skjulstad 2009), and storytelling (several examples in Lundby 2008), to name but some areas of enquiry. A disadvantage is, as Knut Lundby (2009b) has pointed out, that the institutional approach, especially that which leans most heavily on the media logic perspective, often (although naturally not always) brings with it sweeping generalizations, and oversimplifications of the workings of the media. Nick Couldry (2012: 135-136) extends this criticism, questioning whether all media share the same logic, whether this logic is stable or changes over time, and whether this model can actually capture the complex dynamics of the social. Indeed, as Friedrich Krotz (2009: 26) argues: "there is no media logic independent of social and cultural contexts, and independent of history".

Another problem with the institutional perspective on mediatization is that it largely neglects the role of media as technologies in less institutionalized forms. Although there are examples of mediatization processes around which the relationship is not between institutions but between institutions and individual subjects (i.e. children) through "play" (Hjarvard 2013, chapter 5), most institutional perspectives deal with the relationship between journalistic institutions and other institutional spheres in society. It is definitely not overstating the case to say that the mediatization of politics is the dominant perspective in this regard, and that the two institutions of journalism and politics are the most well-researched.

The institutional approach also works within a quite short-term historical perspective. For example, this approach seemingly presupposes that politics at one point in history was independent of the media in society, while at a certain historical moment the media entered the political stage and affected the political process, for example the process of opinion formation. However, this only makes sense if we think of the mass media and journalism as institutions, as modern politics has always involved media as technologies (pamphlets, books, newspapers, etc.). Indeed, Jürgen Habermas' ([1962] 1989) seminal work on the bourgeois public sphere pointed to the 
centrality of privately owned newspapers as the vehicle through which political deliberation occurred, and around which political discussions were centred.

There is of course no denying that political opinion formation has changed in many aspects over the years, even in their less institutionalized forms, and surely the print, electronic, and digital web-based media have been involved in these changes. The question is, however, if they have done so from a position outside society, as Strömbäck seems to imply. As technologies are born and developed within social and cultural frameworks, that is, inside society, it makes little sense to argue that the technologies themselves affect society from outside.

Neither is there any denying that journalism as an institution, or a field, grew increasingly stronger over the 20th century, and has become an important institution "in its own right", as Hjarvard (2008: 113) rightly points out. The institutional perspective on mediatization is, of course, one approach that can be adopted for the analysis of these processes, but there are also other, competing, perspectives that can be adopted, depending on one's research interest (cf. Habermas [1968] 1972).

Elsewhere I have suggested another way of analysing this growth in autonomy of the subfield of journalistic production, within the framework of Bourdieuian field theory (Bolin 2007). However, it can also be analysed as a process of professionalization (e.g. Petersson 2006) or as one of institutionalization (Ekecrantz and Olsson 1994).

\section{The technological perspective}

A very different take on mediatization is represented by what could be called the technological perspective, emphasizing the technological impact on the social and cultural process. These analyses are often on a more abstract historical and societal level, even on the level of modernization. Some would argue that it could also be labelled the "second modernity" perspective (Lundby 2009a: 2). Second modernity is said to follow on a first modernity, supposedly marked by rationality, the nation state and the nuclear family. As argued by Ulrich Beck and Christoph Lau (2005), rather than theorizing the present in terms of postmodernity, a term that suggests that modernity is now over, we should speak of second modernity as there is no clear break in societal development, but rather a "transformation" of the basic institutions of society. Today, in a similar argument Scott Lash (2005) claims that mediatization is "the form that reason takes in second modernity". Lash takes a wide historical grip, taking his departure in the development of reason. The argument is similar to Hjarvard's, in that Lash argues that 'the logic of the media is taking over more and more areas of life' (Lash 2005: 1). However, and contrary to Hjarvard and others who focus on the media as institutions, Lash emphasizes the media as technologies. Where representatives of the institutional perspective highlight institutional forms, Lash talks of "the equivalent to digital media", emphasizing the technological aspect.

The roots of Lash's perspective are to be found among medium theorists such as Marshall McLuhan and Jean Baudrillard. McLuhan, of course, did not use the concept of mediatization, but his most famous slogan "the medium is the message" (McLuhan 1964) indeed suggests that it is the technology and not the institutional form of the media, or the content, that is of importance. Baudrillard does indeed use the concept of mediatization quite early on, and despite Kent Asp's $(1986,1990)$ bold claim to have introduced the term, Baudrillard in fact was already using it at the beginning of the 1970s, for example in the 1971 article "Requiem pour les media" (1971, also in Baudrillard [1972] 1981: 164-185), but more elaborated in his L'échange symbolique et la mort (Baudrillard 1976: 98), later translated into English as Symbolic Exchange and Death (Baudrillard [1976] 1993). Here Baudrillard, in a 
discussion of Walter Benjamin's ([1936] 1977) theses on photography and film in the age of mechanical reproduction as well as Marshall McLuhan's (1964) analysis of the impact of television, discusses the idea of "l'information médiatisée", claiming that today's object "no longer has anything to do with yesterday's object, any more than 'mediatized' information has with the 'reality' of facts" (Baudrillard 1993: 63).

It is quite easy to misread Baudrillard's quote as a suggestion that there is no reality (of facts), which, as Hjarvard (2008: 111) points out, is a simplification of his argument. At the same time it obviously produces ambivalences, as the same Hjarvard argues that Baudrillard, and postmodernist thinkers more generally, "proclaims the disappearance of reality", and has too-grand theoretical claims (Hjarvard 2008: 111). These ambivalences highlight a common misinterpretation of Baudrillard's ideas, likely with roots in an insufficient acknowledgement of the philosophical traditions from which he comes. And although Baudrillard is most often dismissed as a "postmodernist", his thinking is rather rooted in neo-Marxist, structuralist semiology, linguistics, and anthropology. Thus his interest is not in the media as institutions, but rather in the (dis)abilities of the media as technologies to provide for symbolic exchange and communication, and that they provide for simulations of communication, that is, to make us believe we are communicating while we are actually engaged in an empty mimicking of genuine symbolic exchange. And this is a far cry from denying any external reality as such. I will return to this quote, but I first want to take a detour to explain the philosophical roots of Baudrillard's thinking.

Baudrillard has basically two influences: Marxist theories of production and consumption, and Saussurean structural linguistics (and, in its wake, structural anthropology), not least the way the semiological heritage of Saussure was managed by Roland Barthes, for example in his The Fashion System (Barthes [1967] 1990). Rather than proclaiming the disappearance of physical reality, Baudrillard is pointing to a shift in our relation to basic categories of production and consumption, and to 'the object'. If Marx ([1867] 1976) in Capital pointed to a change in our relation to objects under industrialization and the rising capitalist system of production, whereby the fetish character of the commodity stripped the object of its relations to the labour laid down in the production process (by, for example, an artisan), Baudrillard, in a series of five books (1968; [1970] 1998; 1981; [1973] 1975; 1993), points to another shift whereby the emphasis on production has changed to the benefit of consumption, and the sign qualities of commodities.

In traditional political economy from Adam Smith ([1776] 1991) and onwards over Marx and others, the distinction between the use and exchange values of commodities was introduced and theorized. Use value, as described by Marx, is that which fulfils a human need, irrespective of whether this need stems from "the stomach" (material needs), or "the imagination" (immaterial needs) (Marx 1976: 125). All objects that fulfil human needs have use value. Objects that in addition can be sold on a market also have exchange value. Exchange value is produced through human labour (plus raw material), as human labour has the capacity to produce more than it takes to be reproduced.

However, already in the 1950s it was apparent to economists such as John Kenneth Galbraith (1958) that phenomena such as advertising interfered with these laws of economic theory. Baudrillard was indeed influenced by Galbraith (see, e.g. Baudrillard 1998: 70), but took his ideas on the symbolic dimensions of commodities a step further. In line with Galbraith, Baudrillard argued that the signs attached to consumer goods contributed to the exchange value of the commodity. However, he also argued that this "sign value" is also a value in its own right, contributing to the 
status of the consumer when consumed. Furthermore, he argued that what we pay for when buying commodities today is less and less connected to their use value - that is, their functionality - and more and more to the sign value itself. An illustrative example from his $\mathrm{PhD}$ thesis from 1968 - Le système des objets - is the tailfins of American cars. These fins signify "speed", but in their functionality actually do not make the car faster (rather to the contrary). But it is not the functionality of driving fast that the consumer pays for, but rather the sign "speed" in terms of "that is really a fast car". And when consumed by the buyer, this sign value confers to him or her a certain status as "one who drives a really fast car".

Baudrillard thus expanded on the value forms that were introduced in political economy to "utility value, commercial value, statutory value" (Baudrillard 1981: 125). And in Baudrillard's analysis, there is also a shift in emphasis from the functionality of the object, over its commercial qualities as commodity, to its signifying qualities over time (a relative loss of functionality that Lash [2005] also points to). Let us return to the context of the quote in which Baudrillard refers to "mediatized information", by quoting the passage in full:

Every image, every media message and also every surrounding functional object is a test. That is to say, in all the rigour of the term, it triggers response mechanisms in accordance with stereotypes or analytic models. The object today is not 'functional' in the traditional sense of the term: it doesn't serve you, it tests you. It no longer has anything to do with yesterday's object, any more than 'mediatized' information has with the 'reality' of facts. Both object and information already result from a selection, an edited sequence of camera angles, they have already tested 'reality' and have only asked those questions to which it has responded. Reality has been analysed into simple elements which have been recomposed into scenarios of stable oppositions, just as the photographer imposes his own contrasts, lighting and angles onto his object [...]. Thus tested, reality tests you in return according to the same score-card, and you decode it following the same code, inscribed in every message and object like a miniature genetic code (Baudrillard 1993: 63). ${ }^{1}$

This quote illustrates the way Baudrillard sees the changing status of the object, and how he incorporates the fact that the value of the object is of another kind today, compared to historically (although the exact period he is referring to is unclear). What we consume today, he argues, is increasingly the sign value of the object, rather than its functional use value. The reason for this shift can be attributed on the one hand to the organizational principles of "the system of objects" (i.e. capitalist commodity production), and on the other, to the ability of the media to technologically organize communication into a structured code, a kind of structure that Danish linguist Louis Hjelmslev once described as "an autonomous entity of internal dependencies" (quoted from Barthes 1990: 3).

There is no doubt that the structuralist influences from Barthes' The Fashion System shine through here, as fashion is a good example of the dominance of sign value over use value, whereby the "signifier/signified distinction is erased" (Baudrillard 1993: 87). Fashion, however, is based on tangible commodities, produced by a combination of raw material (cloth, linen), labour, and design. In the contemporary world of digital intangible objects and commodities, the principles by which fashion works have extended to non-tangible, digital commodities. In the next 
section I will thus discuss the wider implications of sign value in relation to production in contemporary media and cultural industries.

\subsection{Sign value and the labour of signification}

To Baudrillard, the most important feature of contemporary objects and commodities is their sign qualities. The sign value of commodities as they are conferred on physical objects by, for example, the advertising industry, adds to their economic value according to the logic that consumers are prepared to pay more for a distinctive commodity (one that distinguishes the consumer from his or her fellow consumers in what Bourdieu [1979] (1989) would label a "field of consumption"). To use the analogy of fashion, haute couture is more distinctive than mass-produced clothing from H\&M or GAP. The fashion (de)sign of haute couture is produced through semiotic labour, that is, in the practice of signification carried out by the designer: Alexander McQueen, Vivienne Westwood, and their colleagues. And the exchange value of haute couture is more dependent on the signifying practices of this group of designers than it is on the quality of the raw material they work with (although this naturally also contributes to the exchange value of fashion commodities). This is what Baudrillard (by way of Barthes) hints at when he argues for the dominance of sign value over use value - the function of covering the body, or keeping it warm, is of less importance than the effect of distinguishing the clothes-bearer from his or her contemporaries.

Now, why is an understanding of the fashion system important in the process of mediatization (or, for that matter, anything else outside the fashion system)? This was admittedly a relevant question to Baudrillard at the time his theories were formulated. In his attempts at elaborating Marx's theory of value, Baudrillard wanted to develop a political economy of the sign. However, although he did acknowledge that "the epicentre of the contemporary system is no longer the process of material production" (Baudrillard 1975: 130), which was rooted in his early critique of Marx whom he argued was only useful for analysing "material production" (Baudrillard 1981: 165), he has had surprisingly little to say about the specific character of the opposite, the "immaterial" or intangible commodities supposedly dominant at the time in the late 1960s and early 1970s. It is not surprising, then, that his writings are often incoherent, and that he had obvious difficulty freeing himself of the dominant perspective on commodities as having some kind of material or tangible base. At his best, using examples from fashion and the above-mentioned example of the tailfins of American cars, he could point to instances in which the non-functionality of sign value dominated over functional use value. But he did not formulate a coherent theory of pure sign commodities, that is, commodities entirely constructed of combinations of signs.

However, just as we can say that the ideas of McLuhan are of more obvious relevance today (cf. Merrin 2005: 45), we can hold that the ideas on sign value and the relative importance of signifying practices are of importance if we are to understand the cultural commodities that circulate consumption markets in the digital present - a present that is - if not dominated - then at least heavily marked by sign commodities. Today, with the widespread digitization of the media, it follows that media content to an increasing degree is becoming separated from its tangible carriers. With the sophisticated personal, digital, and mobile means of consumption of today (hardware such as laptops, mobile phones, and tablet computers, and software services such as social networking sites, Spotify, iTunes, Voddler), the cultural object as an assemblage of digits can travel between a range of different tangible carriers. 
Before digitization a piece of music, a novel, a feature film, was bound to its material, physical form: the record, the book, the celluloid film. The object itself - the song, the narrative of the novel, the cinematic film - is a construction composed of an "edited sequence", "scenarios of stable oppositions" that have to be "decoded" according to the "same score-card" they were encoded in. They are pure sign structures that have no tangible base. The semiotic labour of composing the cultural object has its correspondence in the semiotic labour of consuming it.

Sign value, then, as theorized by Baudrillard, is - just as is exchange value the result of the development of the fetish character of the commodity (i.e. the abstracted reified labour) (Baudrillard 1981: 130-142). It contributes to exchange value, as the example of fashion obviously reveals. But it can also be extracted as a value in its own right, which is realized in consumption: the value that differentiates the consumer from other consumers. It therefore also has a relatively autonomous relation to exchange value, and circulates in a different economy, determined by a different logic: that of differentiation. If use value, as theorized by Baudrillard, is coupled with a functional logic, and exchange value with an economic or commercial logic, sign value is coupled with a differential logic (Baudrillard 1981: 123). These logics are governed by the general principles of "utility, equivalence, difference" (Baudrillard 1981: 126). In this sense, sign value replaces neither use nor exchange value, but adds a quality to the object, in the same way as exchange value adds the quality of equivalence to the logic of utility. That something has sign value does not mean it is emptied of use value, but rather that the compositions of value are more complex.

It could be argued that the intertwinement of these logics is more pertinent today, since cultural objects have become freed of their fixation to tangible carriers. A piece of music in its commodity form was previously bound to its tangible carrier. It thus had a material base in raw material as well as the sign qualities. When you buy a piece of music from iTunes today, this is not the case. Arguably, you need the means of consumption to decode the commodity into consumable form, but the commodity itself - the thing you buy from iTunes - has no tangible base. It still has a material quality, of course, since light floating through fibre optic cables also consists of physical energy, but you cannot put the song as a commodity in your pocket or hold it in your hand unless it is laid down on a physical carrier.

The above argument means that the commodity in itself, the thing bought and sold, is a composition of signs without any raw material. There are of course means of production taken advantage of in the process of production (studio space, microphones, instruments, computers), but the act of signification does not tool a raw material into something new. And thus, for the digital commodity, the labour of signification is of crucial importance for its exchange value. Imagine, for example, the production process behind a hit single by Lady Gaga: she or someone else has an idea for a song, a combination of chords and a melody over a beat. When the involved musicians are content with how the tune sounds there will be object form, there will be use value and in the process of marketing and promoting the tune, there will be a commercial form and exchange value added. But what is the signified? The signifier "Bad Romance" as a commodity and object, that is, as a cultural product that has both use and exchange value (it is functional in that you can dance to it, and it has economic value as you can sell it), has no signified besides the tune itself. Of course its individual components in the forms of lyrics, instrumentation, and generic belonging carry a range of connotations, but as a commodity, that is, as a unique 
combination of signs (sounds, timbre, harmonies, etc.), it has no signified besides its own signifier. Furthermore, it shares this quality with all other pure sign commodities.

Admittedly, there were cultural commodities that were pure sign structures before digitization as well. Music pieces as well as television and radio programmes are all examples of non-tangible commodities that existed in the analogue era. But digitization radicalizes the non-tangible sign commodity, if not by quality then by scale, reach, and transformability. As non-tangible objects, however, contrary to tangible commodities that become worn down in use, intangible commodities have a potential for eternal life. This is where the commercial sign system must work at its own destruction in order to close the production-consumption circuit. As tangible commodities wear down with use, non-tangible commodities in sign systems wear down by the signifying practices producing new signs: the fashion of 2014 will be destroyed by the introduction of the fashion of 2015 .

So, to summarize this section, mediatization, as argued by Baudrillard (and his followers, such as Lash 2005), is related to the technological features of the media, rather than the institutional arrangements of the media as media corporations, or the institution of journalism. Instead, the objects and phenomena that are seen as mediatized are subjected to the logic of the medium as a communication technology. Mediatization has to do with form; not in the same way as McLuhan argued that form was the most important effect of the media, but form in the way information and content are subsumed the code imposed by the media. "What is mediatized", argues Baudrillard, "is not what comes off the daily press, out of the tube, or on the radio: it is what is reinterpreted by the sign form, articulated into models, and administered by the code (just as the commodity is not what is produced industrially, but what is mediatized by the exchange value system of abstraction)" (Baudrillard 1981: 175-176).

Mediatization, then, does not result from the impact of technology itself, and neither is it produced by the ways the media are organized into institutions of either mass or personal media. It is rather an effect of the system of signification. This is also where it can be suspected that the root might lie in the misconception of Baudrillard's mediatization concept, and the idea that he is denouncing the existence of reality. What he is arguing for is thus not the disappearance of physical reality, but the increased presence of what could be called self-directed signifiers, that is, signifiers without signifieds or referents outside the sign system itself. But it does not follow from this that these combined signifiers/signifieds are not real. They might be intangible, but they are nonetheless taken account of by consumers and media users in social action. This means that sign structures are real in the sense that they do exist, are acknowledged to exist, and are acted upon in ways that indicate that media users and consumers think of them as existing. Even simulations are real in this sense - as simulations. And signs and simulations are also part of society. Furthermore, it is equally clear that the simulations are born, interpreted and acted upon inside, rather than outside, society. This brings us back to the discussion on the relationship between media as institutions and technologies on the one hand and culture and society on the other, and in the next section I will introduce a third position.

\section{The media as world perspective}

A third, more integrated, approach to mediatization can be labelled the "media as world" perspective, whereby mediatization is regarded as a force, perhaps what Andreas Hepp (2013: 54) has termed a "moulding force", working from within societies (rather than from outside). And indeed, Hepp, his colleague Friedrich Krotz, 
and their research environment at the University of Bremen can be said to work within this tradition, emphasizing "mediatized worlds" (Krotz and Hepp 2011, cf. Krotz 2001).

The roots of this perspective are somewhat harder to trace, and the background is more heterogeneous. Furthermore, although the concept of mediatization is adopted in these debates it is used in a wider sense, referring to the more general role of the media in culture and society. A typical example of this approach can be seen in the following quote from Paul Lazarsfeld's (1941) classic text "Remarks on administrative and critical communications research", where he postulates that "critical research is posed against the practice of administrative research, requiring that, prior and in addition to whatever special purpose is to be served, the general role of our media of communication in the present social system should be studied" (Lazarsfeld 1941: 9). We should note that Lazarsfeld is talking about "the general role of our media of communication in the present social system", which is something quite different from "the independence of politics and society from the media", as Strömbäck (2008: 241) believes. It is also very far removed from the version of mediatization as subsumption under the code advocated by Baudrillard.

So, an underlying presupposition in Lazarsfeld's quote is an integrated social world. It does not ascribe to "the media" an outside position, as either institution or technology. To quote one of the pioneers of Swedish media and communication research, Kjell Nowak, the media are "an integral part of fundamental social and cultural processes, and of human life in contemporary (and past) society" (Nowak 1999: 68, my translation). Lazarsfeld does not use the concept of mediatization, while Nowak does (Nowak 1996: 159-161; 1999: 67). Still, their view on the role of the media in social and cultural processes is nonetheless the same.

Lazarsfeld and Nowak are, of course, not alone in sharing this view on the relationship between our communication media and society. This perspective is far older than that, and some of the influence of what I here call the "media as world" perspective can be attributed to American philosopher John Dewey, who, in his Democracy and Education, proposed that "[s]ociety not only continues to exist by transmission, by communication, but it may fairly be said to exist in transmission, in communication" (Dewey [1916] 1923: 5). This quote was later picked up by James Carey (1975: 2), who used it to distinguish between a transmission and a ritual approach to communication. While the transmission approach privileges causality and linearity in communication, the ritual approach is apt to answer other kinds of questions - on shared meaning, culture, identity. If a society exists both by communication and in communication, it also follows that there are no communicating positions outside society. Surely there might be institutions, and these might have autonomous status in relation to other social institutions (political parties, for example). But these institutions will also be a part of the wider society, and contribute to its specific character. So, the institutional perspective on mediatization as I have described it above has to a great degree adopted a transmission perspective on mediatization, while what I call the media as world perspective is closer to the ritual approach.

This ritual approach is integrative. It does not presume society as atomistic but rather as a whole - encompassing several dimensions, but nonetheless an integrated unity. Its roots are traced by Carey to the functional sociology of Durkheim ([1912] 2001) in his The Elementary Forms of Religious Life, but it can also be found in the writings of Raymond Williams ([1962] 1966), whom Carey (1975: 19) explicitly quotes. However, to me another quote than that referred to by Carey, taken from the 
same chapter in Williams's Communications, is more fitting for illustrating the ritual view on the relationship between media and society:

Many people seem to assume as a matter of course that there is, first, reality, and then, second, communication about it. We degrade art and learning by supposing that they are always second-hand activities: that there is life, and then afterwards there are these accounts of it. [...] We need to say what many of us know in experience: that the life of man, and the business of society, cannot be confined to these ends; that the struggle to learn, to describe, to understand, to educate, is a central and necessary part of our humanity. This struggle is not begun, at second hand, after reality has occurred. It is, in itself, a major way in which reality is continually formed and changed. What we call society is not only a network of political and economic arrangements, but also a process of learning and communication (Williams 1966: 19).

It is quite clear from the quoted passage that Williams opposes a view that separates mediated communication from reality, and is especially opposed to denigrating communication and art to "second-hand activities". These are rather to be seen as "a central and necessary part" of society. In this sense the representations, accounts, stories, and ideas of individuals are part of social reality just as much as are the more physical objects society also comprises.

The ritual perspective does not primarily analyse casual effects, directions of influence and impact. Although it is also involved in descriptive analysis of the state of the media, seeking answer to the question "What does it look like?", it is equally occupied with the analysis of meaning. It thus adds the subjectivist question "What does it feel like?" to the objectivist descriptive approach. ${ }^{2}$ It focuses not only on the materiality of social and cultural relations but also on subjective perceptions of them. This is sometimes theorized as an oscillation between the two perspectives, a will to overcome the objectivist/subjectivist divide. One example of such an approach is the "constructivist structuralism" of Pierre Bourdieu ([1987] 1990: 123). This approach holds at its centre the axiomatic view that social structures have come into being as a result of social actions formed not only by the objective structures that structure behaviour, but just as much by the agent's interpretations of these structures. As David Morley (1997: 126) once formulated it, "macro structures can only be reproduced through micro-processes", and these micro-macro relations can only be studied if one tries to understand the world-views of individual subjects related to the structuring constraints of previous social action. This is, of course, a classical tension between structure and agency, which has also been formulated by Marx: "Men make their own history, but they do not make it as they please; they do not make it under self-selected circumstances, but under circumstances existing already, given and transmitted from the past" (Marx [1852] 1995). The "circumstances" mentioned by Marx have been formed by previous generations, who in turn have acted within the structural constraints as well as possibilities of even earlier generations, in a perpetual generational spiral. The constraints as well as the possibilities to overcome them include all the structuring institutional arrangements made in culture and society, which develop in conjunction with each other. However, the ritual view need not necessarily encompass a linear historical explanation, but is rather open to alternative historical understandings, taking their departure in alternative conceptualizations of historical time alongside the linear, for example in circular time (emphasizing its 
repetitive, ritualistic quality) or even punctual time (whereby time is defined not by its succession of moments but by its social or cultural quality).

This is also a perspective on social and cultural development that could emphasize the role of the media not in terms of causality but as archive, as a common intellectual resource, a heritage that includes prehistoric art and literature, early forms of communication and cultural formation, cultural practices, the assemblage of cultural technologies at our disposal in the form of both technological hardware (machines of different kinds) and technological software, that is, the various techniques men and women have developed for communication (the signifying practice of language as such, poetry, genres, and other presentational forms, etc.) - in sum, all the things that have played a part in the forming of our present social and cultural worlds: the poetry of Homer; the cave paintings of Altamira, Spain; the archaic, Akkadian and Assyrian cuneiform tablets; the Gilgamesh epic.

In this approach mediatization points more to the roles of the hardware and software of communication in society and how we as social and cultural beings form - and are formed by - the surrounding media landscape as "material and mental environment" (Nowak 1996). Mediatization, then, points to the increased presence of the media as technologies in society, and the consequences of this on its qualitative character (Hannerz 1990; cf. Fornäs 1995). According to Nowak (1996: 164-166), social and cultural action is carried out within as well as with and through the media environment. First, we communicate within an increasingly media rich environment where we have access to increasingly many and more differentiated media technologies. Second, these media technologies increasingly allow human-machine interaction, so that we more often communicate with technology, for example with Apple's "intelligent assistant" Siri, who "understands what you say, knows what you mean, and has the answers you need". 3 Third, we naturally communicate through technologies such as e-mail, SMS and chat rooms, mobile phones, etc. And if society, as Dewey (1923) argues, exists in communication, this is indeed an increasingly technified - mediatized - form of communication. In combination, these increased communicative possibilities make us live a virtual "media life", as Mark Deuze (2012) argues in a similar way to Nowak, albeit updated to the contemporary media environment. This media life is virtual, not in the sense of "fake" or "simulated" but in the sense of that which "is so in essence or effect". ${ }^{4}$ It is a "real fact" according to the logic that holds that "[i]f men define situations as real, they are real in their consequences", as the Thomas theorem goes (Merton [1949] 1957: 421-422). In this sense, Baudrillard's simulations and simulacra are real in their consequences, which is why they should not be dismissed as not having to do with reality. And in this sense, we should acknowledge some mediated phenomena produced in an increasingly mediatized communication environment as important instances of late modern media life. Let me conclude the discussion by giving some examples of media phenomena that indeed have an impact on the character of society, but are difficult to analyse in terms of the media imposing themselves on a supposedly previously unmediated phenomenon. Two such examples are the media event (the Eurovision Song Contest, the Olympics) and the sign commodity (texts, audiences, formats, the brand). These phenomena have little existence outside the media, either as institutions or technologies. Nonetheless, they need to be seen as social and cultural phenomena that are clearly part of our present social realities.

\section{Objects and commodities in a media(tized) world}


In this last section I want to briefly discuss some late modern phenomena that are indicative of our mediatized worlds of the present. They have been chosen because they are examples of phenomena that do not pretend to represent or make a mediated account of a social reality outside the institution of the media, but nonetheless need to be considered part of everyday social reality.

The first example is the Olympic Games in their modern form. While these games do indeed have an unmediated prehistory dating back to ancient Greece (ca. $776 \mathrm{BC}$ to $394 \mathrm{AD}$ ), it should be noted that the modern games as introduced in 1896 by Pierre de Coubertin appear during the era of mass communication: the mass press, and the new medium of cinematic film. The modern games are also, contrary to the ancient games, international. This presupposes some form of communication medium to report back to the partaking national audiences. Indeed, it would be peculiar if one arranged an international competition of supposedly great national interest if there were no means to report back to citizens of partaking nation-states.

We can thus argue that the modern Olympic Games have never occurred in unmediatized form. The media as technologies and as institutions (sports journalism) have always been an integrated part and a main component. Admittedly, the media technologies have changed since 1896, which has had an impact on the ways the Olympic Games have been mediated back to national audiences, the ways they have been represented. But there has never been an unmediated Olympic moment in the modern era. The Olympic Games are mediated in the meaning that they develop in tandem with the media organizations and technologies involved in their mediation to national audiences.

Perhaps even more striking in this respect is a phenomenon like the Eurovision Song Contest (ESC). This long-standing institution in European television history, initiated in 1956 by the European Broadcasting Union (EBU) and broadcast yearly to European (and some other) audiences, was in fact initiated as a cultural technology (Bolin 2012) to communify the European countries through a common entertainment competition. From having been a limited phenomenon at its start (only seven countries took part in the first competition), it has today grown to be one of the largest non-sport media events in Europe.

As a production initiated by the EBU, however, it has little life separate from the media; that is, if by media we mean the integrated efforts of television, the Internet, the tabloid press, weeklies and fan press, as well as the music media - record companies, streaming services, and others with an interest in making revenues out of the music. From an institutional perspective, the ESC is an institution in its own right. It naturally affects other media institutions, including journalism, but it makes little sense to say that this conglomerate of media technologies and institutions has an impact on other non-media institutions in society, as the media form is always already there. There is no unmediated version of ESC that can be affected, and although there is a live studio audience present at each final, the production is clearly not aimed at these individuals but rather at the viewing audience in countries all over Europe (Bolin 2006: 202).

Most media commodities today also have the characteristic of being sign commodities. ${ }^{5}$ The most obvious example is the media text, or, as the industry jargon goes, content. The first of these appears with broadcasting technology, whereby the radio programme or television show, initially broadcast live, consists of nothing but airwaves. Indeed, this is just the point Thomas Streeter made when he called his book on the history of commercial broadcasting policy in the US Selling the Air (Streeter 1996). The commodity at the basis of the commercial broadcasting system was a 
combination of signs that were technologically encoded and decoded in the transfer from broadcaster to the viewing and listening audience. Broadcasting was analogue, at least initially, and with digitization this quality is further established. However, with digitization even media texts that were previously not pure sign structures but were rather firmly bound to their tangible carriers - for example the book or the newspaper - now became intangible and versatile, and could float between technological platforms of storage and distribution. With digitization, then, many (if not most) media texts become pure sign commodities.

A specific content form is the format, that is, the basic idea for the production of a television show (often in the reality genres) that allows for national adaptation. Formats are a specific kind of commodity that is bought and sold at the large television MIP-TV and MIPCOM fairs in Cannes, France, and other places in the world. In the words of Australian television researcher Albert Moran, in turn quoting a television producer, a format is similar to a pie, whereby "the crust is the same from week to week but the filling changes" (Moran 2004: 5). However, this crust is, contrary to the crust in an apple pie, not possible to put on a plate, and it is consumed in its sign form, as a principle for how to put together and produce a television show. This is also why the legal frameworks protecting this commodity are so weak, which makes this specific market for formats totally reliant on the common belief among those involved in the commodity. If the involved parties of buyers and sellers were to doubt the value of the commodity, the market would disappear instantly.

A second sign commodity that appears, not with digitization but rather with the rationalizations of the commercial mass media, is the audience. Audiences, if we distinguish this commodity based on statistical aggregation from the social subjects who listen, read, and watch mass media, have become an increasingly sophisticated statistical construct. This commodity is worked upon by the marketing and audience analysis divisions of large media companies, and is tooled into the commodity that is the basis of their revenues. This construct is based on mathematical calculation, estimations and probability theory through a range of data-generating technologies: telephone and postal surveys, people meters, user panels, etc. Although there have been dramatic advances in methodology, all these techniques share the disadvantage that they do not represent social reality $1: 1$. They are estimates, ranging from pure guesswork to statistical descriptions with high significance - but they never equal social reality. They are merely representations of this social reality, and the basis for the calculation of prices for advertising (or other marketing techniques). The commodity sold is based on the common agreement between seller and buyer on a price, and the mutual belief that the calculated statistics are good enough. Like any other market, the audience market is based on the belief that the signifier - the figure indicating the size and composition of the audience - has a referent in social reality (cf. Galbraith 1970).

A third sign commodity is traffic. In the digital world, media users have increasing access to means of production and distribution on social networking sites and other forums that, as their business model, have user traffic at their centre. The tightened bonds between the telecommunications industry and other parts of the media and advertising industries mean that much of the media economy builds on bytes transferred through fibre optic cables or Wi-Fi networks. In such an economy even waste turns into economic value, because it matters very little to the telecommunications companies what content flows through their networks as long as it produces traffic. Illegal downloading is then also to the benefit of these companies, as is spam mail. Spam mail, in fact, is a very peculiar entity in this economic circuit. 
Most of it is never opened by its addressee, and quite often it goes directly, via spam filters, to the waste-basket. Nonetheless, it contributes to the "traffic commodity" (Van Couvering 2008). This is, however, a general kind of traffic commodity. Through new business models and opportunities provided for by digitization, there has also appeared a specific traffic commodity. As the telecommunications companies - our telephone and Internet service providers - have access to the data we as users produce, they can also map out our behaviour on the web and produce user behaviour profiles. The websites we visit, the patterns of our e-mail correspondence, our patterns of search on Google, Yahoo! or bing, our postings on social networking sites like Facebook, produce information that can then be sold to third parties to take advantage of through cleverly constructed algorithms that provide us with tailored marketing messages. And all these commodities have the quality of being intangible. They consist of aggregated information in large data banks that can be harvested and turned into economic value by those who control the communication flows.

My fourth example of a sign commodity is the brand. A brand can be described as a complex signifier, constructed in semiotic labour with the purpose of producing a specific signified connected to a company or a consumer commodity. The brand is the most obvious sign commodity, as it is a construct that everyone acknowledges as a construct. A brand is descriptive as well as prescriptive. It is "a practical effort to make the world conform to the structures of the conceptual" (Carrier 1998: 2, quoted in Moor 2007: 5). As such it works at the level of the sign, and is thus subsumed by the laws of signification. In the traditional industrial production of tangible commodities, brand differentiation was adopted as a strategy to separate one commodity from another within the same functional area. With increased market competition, branding strategies became more important, and hence the sign value of commodities, as the value brands are built on, gradually took command over the functional use values of objects and commodities, and the sign value itself became the most important object of consumption (Baudrillard 1968: 229). We need only take a quick look at the mobile phone market to realize that brand recognition is more important than the technological information of functionality; Apple has been particularly successful through their (de)sign strategies, creating hype around their products, most notably the iPhone and iPad. A strong consumer demand is created through this, built less on functionality and more on sign appearance: "iPhone 5 - The biggest thing to happen to iPhone since iPhone", as the self-hype on Apple's web pages goes. This slogan is followed in an animated row by six other slogans, the first dealing with its design and the next five with its functionality (technical performance, new application features, etc.). ${ }^{6}$ Design is thus the first and most important argument in the brand construction of Apple's iPhone.

These four kinds of sign commodities arguably are indicative of how contemporary media industries work. This is an aspect of "the media" - as institutions and technologies - that is not truly possible to grasp only with the institutional or the technological mediatization perspective alone, and as these examples reveal, there is a need to take seriously the workings of communicative signification as well as approaches rooted in phenomenology and social constructionism if we are to understand contemporary media landscapes. The second modernity perspective, with its roots in linguistic, anthropological, and (post-)structuralist theory, and the world perspective in phenomenology need to be brought together and seen as complementary rather than as rivals, as they highlight different aspects of these roles of the media. Or, to phrase it differently, if we cannot consider the institutional power relations in conjunction with the specificities of both technological and 
communicative form, and if these cannot be related to the subjective apprehensions of media users and producers, we have little chance of capturing the complexities of late modern media cultures and societies.

\section{Conclusion}

In the above I have tried to discuss three strands of, or approaches to, mediatization theory. First, I have discussed the institutional perspective, with its mainly causal explanatory approach, leaning towards a linear, transmission perspective, based in an historical view that could be described as close to a modernization perspective. As the focus is on the impact of the media as an institution affecting social processes, it mainly theorizes the media as a phenomenon that works on social institutions from the outside. This is mediatization as institutional impact, and the logic emphasized is that of the institution.

Second, I have accounted for the technological perspective, which is based in linguistics, structural anthropology, semiotics, and Marxism, arguing that we have now entered a second modernity, and emphasizing the play of signifiers, sign value, and a media and cultural production process marked by signifying practices. The historical view is not necessarily linear, although there are also strong such influences. The role of the media in this perspective is on the level of form, and concerns how it provides a code that is decisive for the quality and character of communication. This is mediatization as communicative quality. The logic forefronted is that of the sign, and the impact of signification and difference.

The first and second perspectives are both centred on a specific, processual view on history. In the first case linearity and causality are emphasized, while the second approach, in line with its post-structuralist influences, forefronts the break with previous historical developments. But this is also a perspective informed by linear thinking, as you can only introduce a break if there is a previously formed, continuous succession of events. However, both have very little to say about individual action, the dynamics of media use, or the consequences of perception on the structural matrixes that form our cultures and societies.

Third, I have pointed to the media as world perspective, rooted in phenomenology and social constructionism, and with a clearer, integrative approach to the relationship between media, culture, and society. It shares with the second perspective an emphasis on the production and sharing of meaning, but is less poststructural and rather rooted in constructionist approaches and the will to overcome the micro-macro divide in theory. If there is a logic emphasized - and it should be stressed that the concept of logic fits less well within this paradigm - it is to be found in the interplay between a logic of relations and a logic of the social, of action. Within the world perspective the interpretive actions of human subjects are acknowledged, and contrary to post-structural sign theories, whereby meaning is produced as an effect of signification, the world perspective has a sensitivity to the range of interpretations made, all resulting from the variations in different experiences of the human subjects. This is the "constructivist structuralism" argued for by Bourdieu, or the lived experience of Williams, and it also appears at the bottom of theories such as the encoding/decoding perspective of Hall ([1973] 1980), and so on. These are all approaches that have tried to overcome some of the problems that at the bottom line can be traced back to the classical tensions in the philosophy of science: subjectivism-objectivism, structure-agency, individual-society. They are, of course, not solved by the arguments above, but their reappearance is constantly provoked by 
the continuously new constellations and relational conditions of the media, culture, and society.

\section{References}

Altheide, David L. and Robert P. Snow 1979 Media Logic. Beverly Hills: Sage.

Asp, Kent 1986 Mäktiga Massmedier. (Powerful Mass Media). Stockholm: Akademilitteratur.

Asp, Kent 1990 Medialization, media logic and mediarchy. Nordicom Review 112: 47-50.

Barthes, Roland 1990 The Fashion System. Berkeley: University of California Press. First published [1967].

Baudrillard, Jean 1968 Le Système des objets. Paris: Gallimard.

Baudrillard, Jean 1998 The Consumer Society. Myths and Structures. London: Sage. First published [1970].

Baudrillard, Jean 1971 Requiem pour les Media. Utopie 4: 35-51.

Baudrillard, Jean 1981 For a Critique of the Political Economy of the Sign. St Louis: Telos. First published [1972].

Baudrillard, Jean 1975 The Mirror of Production. St Louis: Telos. First published [1973].

Baudrillard, Jean 1976 L'échange symbolique et la mort. Paris: Gallimard. Baudrillard, Jean 1993 Symbolic Exchange and Death. London: Sage. First published [1976].

Beck, Ulrich and Christoph Lau 2005 Second modernity as research agenda: Theoretical and empirical explorations in the "meta-change" of modern society. British Journal of Sociology 564: 525-557.

Benjamin, Walter 1977 The work of art in the age of mechanical reproduction. In: James Curran, Michael Gurevitch and Janet Wollacott (eds.), Mass Communication and Society, 384-408. London: Edward Arnold. First published [1936].

Bolin, Göran 2006 Visions of Europe. Cultural technologies of nation states. International Journal of Cultural Studies 92: 189-206. 
Bolin, Göran 2007 The politics of cultural production. The journalistic field, television and politics. In: Kristina Riegert (ed.), Politicotainment. Television's Take on the Real, 59-82. New York: Peter Lang.

Bolin, Göran 2011 Value and the Media. Cultural Production and Consumption in Digital Markets. Farnham: Ashgate.

Bolin, Göran 2012 Cultural technologies in cultures of technology. In: Göran Bolin (ed.), Cultural Technologies. The Shaping of Culture in Media and Society, 115. New York: Routledge.

Bourdieu, Pierre 1989 Distinction. A Social Critique of the Judgement of Taste. London: Routledge. First published [1979].

Bourdieu, Pierre 1990 Social space and symbolic power. In: In Other Words. Essays Towards a Reflexive Sociology, 123-139. Cambridge: Polity. First published [1987].

Carey, James 1975 A ritual approach to communication. Communication 21: 1-22.

Carrier, James 1998 Introduction. In: James Carrier and Daniel Miller (eds.), Virtualism: A New Political Economy, 1-24. Oxford \& New York: Berg.

Couldry, Nick 2012 Media, Society, World. Social Theory and Digital Media Practice. Cambridge: Polity.

Deuze, Mark 2012 Media Life. Cambridge: Polity.

Dewey, John 1923 Democracy and Education. An Introduction to the Philosophy of Education. New York: Macmillan. First published [1916].

Durkheim, Émile 2001 The Elementary Forms of Religious Life. Oxford: Oxford University Press. First published [1912].

Ekecrantz, Jan and Tom Olsson 1994 Det redigerade samhället. Om journalistikens, beskrivningsmaktens och det informerade förnuftets historia. (The Edited Society. On Journalism, Description Power and the History of Informed Reason). Stockholm: Carlssons.

Fornäs, Johan 1995 Cultural Theory and Late Modernity. London: Sage.

Galbraith, John Kenneth 1958 The Affluent Society. New York: Mentor.

Galbraith, John Kenneth 1970 Economics as a system of belief. American Economic Review 602: 469-478. 
Habermas, Jürgen 1972 Knowledge and Human Interest. London: Heinemann. First published [1968].

Habermas, Jürgen 1989 The Structural Transformation of the Public Sphere. An Inquiry Into a Category of Bourgeois Society. Cambridge, MA: MIT Press. First published [1962].

Hall, Stuart 1973 Encoding/Decoding in the Television Discourse. Stencilled occasional paper from CCCS no. 7. Birmingham: Birmingham University/CCCS.

Hannerz, Ulf 1990 Genomsyrade av medier. (Saturated by media). In: Ulf Hannerz (ed.), Medier och kulturer (Media and Culture), 7-28. Stockholm: Carlssons.

Hepp, Andreas 2013 Cultures of Mediatization. Cambridge: Polity. First published [2011].

Hjarvard, Stig 2008 The mediatization of society. A theory of the media as agents of social and cultural change. Nordicom Review 29: 105-134.

Hjarvard, Stig 2013 The Mediatization of Culture and Society. London \& New York: Routledge.

Hjarvard, Stig and Mia Lövheim (eds.) 2012 Mediatization and Religion. Nordic Perspectives. Göteborg: Nordicom.

Krotz, Friedrich 2001 Die Mediatisierung kommunikativen Handelns. Der Wandel von Alltag und sozialen Beziehungen, Kultur und Gesellschaft durch die Medien. Wiesbaden: Westdeutcher Verlag.

Krotz, Friedrich 2007 The meta-process of "mediatization" as a conceptual frame. Global Media and Communication 33: 256-260.

Krotz, Friedrich 2009 Mediatization: A concept with which to grasp media and societal change. In: Knut Lundby (ed.), Mediatization. Concept, Changes, Consequences, 21-40. New York: Peter Lang.

Krotz, Friedrich and Andreas Hepp 2011 A concretization of mediatization: How mediatization works and why "mediatized worlds" are a helpful concept for empirical mediatization research. Empedocies: European Journal for the Philosophy of Communication 32: 119-134.

Lash, Scott 2005 Intensive media - modernity and algorithm. Roundtable. Research Architecture. London: Centre for Research Architecture, Goldsmiths' College, University of London. Retrieved December 4, 2012, from http://roundtable.kein.org/node/125. 
Lazarsfeld, Paul F. 1941 Remarks on administrative and critical communications research. Studies in Philosophy and Social Science 91: 2-16.

Lundby, Knut 2008 Digital Storytelling, Mediatized Stories. Self-Representations in New Media. New York: Peter Lang.

Lundby, Knut 2009a Introduction: "Mediatization" as a key. In: Knut Lundby (ed.), Mediatization. Concept, Changes, Consequences, 1-18. New York: Peter Lang.

Lundby, Knut 2009b Media logic: looking for social interaction. In: Knut Lundby (ed.), Mediatization. Concept, Changes, Consequences, 101-119. New York: Peter Lang.

Marx, Karl 1976 Capital. A Critique of Political Economy. Volume One. London: Penguin Books. First published [1867].

Marx, Karl 1995 The Eighteenth Brumaire of Louis Bonaparte. Retrieved January 21, 2013, from http://marxists.org/archive/marx/works/1852/18th-brumaire/. First published [1852].

Mazzoleni, Gianpietro and Winfried Schulz 1999 "Mediatization" of politics: A challenge for democracy? Political Communication 163: 247-261.

McLuhan, Marshall 1964 Understanding Media: The Extensions of Man. New York: McGraw-Hill.

McQuail, Denis 2006 On the mediatization of war. A review article. The International Communication Gazette 748: 104-118.

Merrin, William 2005 Baudrillard and the Media. Cambridge: Polity.

Merton, Robert K. 1957 Social Theory and Social Structure. Glencloe/London: The Free Press/Collier-Macmillan. First published [1949].

Moor, Liz 2007 The Rise of Brands. New York: Berg.

Moran, Albert 2004 Television formats of the world/the world of television formats. In: Albert Moran and Michael Keane (eds.), Television Across Asia. Television Industries, Programme Formats and Globalisation, 1-8. London \& New York: RoutledgeCurzon.

Morley, David 1997 Theoretical orthodoxies: Textualism, constructivism and the "new ethnography" in cultural studies. In: Peter Golding and Marjorie Ferguson (eds.), Cultural Studies in Question, 121-137. London: Sage. 
Nowak, Kjell 1996 Medier som materiell och mental miljö. (Media as material and mental environment). In: Ulla Carlsson (ed.), Medierna i samhället: Igår, idag, imorgon (Media in Society: Today, Yesterday and Tomorrow), 159-176. Göteborg: Nordicom.

Nowak, Kjell 1999 Medieutvecklingen och vardagen. (The media development and everyday life). In Ulla Carlsson (ed.) Medierna i samhället. Kontinuitet och förändring (Media in Society: Continuity and Change), 65-68. Göteborg: Nordicom.

Petersson, Birgit 2006 Från journalist till murvel. Journalistyrkets professionalisering från 1900 till 1960-talet. (From Journalist to Hack: The Professionalization of Journalism as a Vocation). Göteborg: Nordicom.

Skjulstad, Synne 2009 Dressing up: The mediatization of fashion online. In: Knut Lundby (ed.), Mediatization. Concept, Changes, Consequences, 179-202. New York: Peter Lang.

Smith, Adam 1991 The Wealth of Nations. New York: Alfred A. Knopf. First published [1776].

Streeter, Thomas 1996 Selling the Air. A Critique of the Policy of Commercial Broadcasting in the United States. Chicago and London: University of Chicago Press.

Strömbäck, Jesper 2008 Four phases of mediatization: An analysis of the mediatization of politics. International Journal of Press/Politics 133: 228-246.

Van Couvering, Elizabeth 2008 The history of the internet search engine: navigational media and the traffic commodity. Information Science and Knowledge Management 14: 177-206.

Williams, Raymond 1966 Communications. Harmondsworth: Penguin. First published [1962]

\footnotetext{
${ }^{1}$ It should be noted that in the French original, "reality" is put in quotation marks in the passage, whereas "l'information médiatisée" is not (contrary to the English translation).

${ }^{2}$ It should be pointed out that although Baudrillard's techno-structural perspective is hard to combine with a subjectivist approach, just like all hyper-structuralist accounts, the institutional perspective does not rule out subjectivist approaches. The institutional perspectives of mediatization, however, seem to be less interested in this aspect (but see Hjarvard 2013: 137ff).

${ }^{3}$ Quoted from http://apple.com/iphone/built-in-apps/, accessed 21 January 2013.

${ }^{4}$ Oxford English Dictionary, www.oed.com, entry: virtual. Accessed 21 January 2013.

${ }^{5}$ This section builds on a much more elaborated discussion on sign commodities in Bolin (2011: 117ff).
} 
${ }^{6}$ Retrieved January 23, 2013, from http://apple.com/uk/iphone/. 